\title{
Effect of virginiamycin and bovine somatotropin on growth, nutrient conversion and blood parameter in young female calves
}

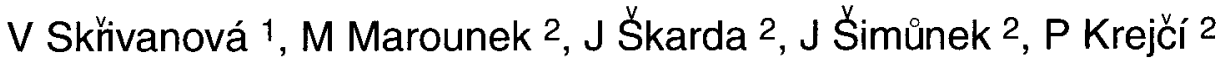 \\ 1 Institute of Animal Production; \\ 2 Institute of Animal Physiology and Genetics, Czech Academy of Sciences, \\ Prague 10, Uhr'inèves, Czech Republic
}

(Received 17 July 1995; accepted 29 February 1996)

\begin{abstract}
Summary - Experiments were conducted on 20 female calves (Bohemian red spotted $x$ Friesian), housed in individual stables and offered milk, concentrate mixture and hay to meet the nutrient requirements for maintenance and growth at $85 \%$ of NRC (1978) recommended requirements. Calves, initially 21 to 24 days old, were allotted to four different treatments. Calves in the first group were treated subcutaneously with olive oil at 7 day intervals (control). The second group received injections of olive oil and a daily oral dose of virginiamycin (a feed antibiotic), $80 \mathrm{mg}$ per animal. The third group received subcutaneous (sc) injections of recombinant methionyl bovine somatotropin (bST) in a sustainedrelease vehicle (100 $\mathrm{mg}$ per head) in 7 day intervals. The fourth group received both virginiamycin and bST. The experiment lasted for 70 days. Control calves gained, on average, $0.52 \mathrm{~kg}_{\text {day }}{ }^{-1}$. Both growth promotors appeared to improve weight gain and feed efficiency. The effects of virginiamycin and bST were additive. Virginiamycin, bST and a combination of bST and virginiamycin improved gains by $9.6,5.8$ and $15.4 \%$, respectively. Only the effect of bST and virginiamycin in combination, however, was significant $(P<0.05)$. Blood haemoglobin and serum glucose, protein and cholesterol were not significantly affected. The plasma bST concentration was up to ten-fold higher in the bST-treated groups then in the control and virginiamycin-treated groups. The effect of virginiamycin on the plasma bST concentration was not significant.
\end{abstract}

calves / virginiamycin / bovine somatotropin

Résumé - Effet de la virginiamycine et de la somatotropine bovine sur la croissance, l'efficacité alimentaire et les paramètres du sang chez les génisses. L'essai a été réalisé sur 20 génisses (Pie Rouge Tchèque $x$ Frisonne). Les génisses, maintenues en cases individuelles, ont reçu du lait, un aliment concentré et du foin pour couvrir à $85 \%$ des normes NRC (1978) leurs besoins d'entretien et de croissance. Les génisses, âgées de 21 à 24 jours, ont été réparties en quatre lots. Les génisses du lot 1 ont reçu une injection sous-cutanée d'huile d'olive, tous les 7 jours. Celles du lot 2 ont reçu, outre les injections d'huile d'olive, $80 \mathrm{mg}$ par jour de virginiamycine par voie orale. Celles du lot 3 ont reçu des 
injections de $100 \mathrm{mg}$ de méthionyl bST recombinée (forme retard) tous les 7 jours. Celles du lot 4 ont reçu à la fois de la virginiamycine et de la bST. L'essai a duré 70 jours. Les génisses du lot 1 (témoin) ont gagné en moyenne 0,52 kg/jour. La virginiamycine et la bST ont eu tendance à améliorer le gain de poids vif et l'efficacité alimentaire, mais seule leur combinaison a eu un effet significatif $(\mathrm{p}<0,05)$ : le gain de poids vif a été accru de $9,6 \%$ avec la virginiamycine, de $5,8 \%$ avec la bST et de $15,4 \%$ avec la combinaison des deux. Le taux sanguin d'hémoglobine et les taux sériques de glucose, de protéines et de cholestérol n'ont pas été significativement modifiés. En revanche, la bST, mais non la virginiamycine, a significativement augmenté la teneur du plasma sanguin en hormone de croissance.

génisse / virginiamycine / hormone de croissance

\section{INTRODUCTION}

It is widely accepted that antimicrobial feed additives, $\beta$-adrenergic agonists and anabolic hormones can improve animal growth and protein deposition. The use of growth-promoting agents and, in particular, feed antibiotics in calves has been the subject of many studies. A number of authors have examined the effect of monensin (Ilan et al, 1981; Marounek et al, 1989), virginiamycin (Daenicke, 1988; Skř̀ivanová and Marounek, 1993; Skřivanová et al, 1994), lasalocid (Anderson et al, 1988), avoparcin (Moughan et al, 1989) and aureomycin (Brown et al, 1960) as feed supplements. In general, these authors investigated the effect of feed antibiotics on performance, feed efficiency, digestibility of nutrients, ruminal parameters and blood variables. Other aspects of feed antibiotic supplementation have generally been neglected in most studies. The growth of young ruminants is a very complex and highly integrated process, which depends on the nutrient supply and general status of the animal. It is controlled by numerous hormones and growth factors. Although somatotropin is the most important hormone in this respect, its effect is only part of the whole hormonal regulatory mechanism. Several authors have investigated the effect of bovine somatotropin (bST) on the growth of calves. Pituitaryderived bST (110 $\mu \mathrm{g} . \mathrm{kg}^{-1}$.day-1) increased the weight gain of 3-month-old ruminant female calves by $10 \%$ in the experiment of Brumby (1959). Similar results were obtained by Sandles and Peel (1987) in heifers treated with $600 \mu \mathrm{g} \mathrm{bST. \textrm {kg } ^ { - 1 } \text { .day }}{ }^{-1}$.

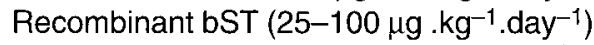
increased the average daily gain of 6-weekold female veal calves by $7.1-10.8 \%$ (Kirchgessner et al, 1987). The responses of young bulls (2-3 weeks old), however, have been variable. In the experiments of Williams et al (1987), bST treatment failed to improve weight gain of veal calves; however, in those of Groenewegen et al (1990), a significant increase of body weight gain was found in weaned calves.

The aim of this study was to compare the growth rate and hormone profiles in female calves treated with virginiamycin and bST. The data demonstrated that both growth enhancers could improve the performance of calves and that their effects were additive.

\section{MATERIALS AND METHODS}

Twenty crossbred female calves (Bohemian red spotted $x$ Friesian) purchased from commercial dairy farms at 2 weeks of age were used in the experiment. The calves were individually penned and were given a 7 day acclimatization period prior to beginning the treatments. They were then assigned to one of four groups (consisting of five animals each). The calves did not differ by more than 3 days of age. The first group of calves (control) received subcutaneous (sc) injections of olive oil $(0.4 \mathrm{ml})$ at 7 day intervals for 70 days. The 
second group (V) received sc injections of olive oil at 7 day intervals and a daily oral dose of $80 \mathrm{mg}$ virginiamycin (Smith Kline Beecham, Belgium) per animal, in capsule form. The third group (bST) received sc injections of recombinant methionyl bST in a sustained-release vehicle $(100 \mathrm{mg}$ per animal per 7 days; Somatech ${ }^{\circledR}$, a gift from Monsanto Agricultural Co, USA). The fourth group $(b S T+V)$ received both virginiamycin and bST (as described earlier). The calves were fed with skimmed milk at 0600 and at 1600 hours. Undiluted milk was fed at $3.5 \mathrm{~L}$ per day until 4 weeks of age, then milk diluted with water 3:2 (in the fifth week) and 1:1 (until 7 weeks of age). Calves were weaned from milk at 7 weeks of age. The daily amount of meadow hay offered increased stepwise from 0.05 to $0.9 \mathrm{~kg}$. The daily amount of concentrate offered increased from 0.1 to $1.5 \mathrm{~kg}$ and that of maize silage ( $28 \%$ dry matter [DM]) from 0.2 to $1.1 \mathrm{~kg}$. Silage was fed from 10 weeks of age. Dietary components were fed to meet nutrient requirements for maintenance and growth at $85 \%$ of NRC (1978) recommended requirements. The weights of calves were recorded once a week. Blood samples for bST analysis were taken by jugular venipuncture before and after the last injection of bST. Heparin was used as an anticoagulant. Blood variables were recorded once a week. A portion of the blood sample was stabilized using heparin. The remaining blood was left standing to obtain serum.

Concentration of bST in the plasma was determined by radioimmunoassay as previously described (Slaba et al, 1994) with pituitary-derived bST, purified by chromatography on SE. Sephadex C-50 in sodium acetate buffer (potency: $1.4 \mathrm{IU}_{\mathrm{mg}}{ }^{-1}$ ) for iodination and reference standards. The first antibody was produced in rabbits against pituitary-derived bST NIH-GHB-1003A (a gift from the National Institute of Health, Bethesda, MD, USA) conjugated with human serum albumin by means of tolylene-2.4diisocyanate according to Likhite and Sehon (1967). The second antibody was produced against bovine $\gamma$-globulin in pigs (SwAR/G-RIA, Sevac, Institute of Sera and Vaccines, Prague, Czech Republic). Iodination of bST was performed by the lactoperoxidase method (Thorell and Johansson, 1971) with lactoperoxidase (B grade from Calbiochem, Los Angeles, CA, USA) using ${ }^{125} \mathrm{I}\left(\mathrm{Na}{ }^{125} \mathrm{l}\right.$, carrier free) from Amersham International (Amersham, UK). Intra- and interassay coefficients of variation averaged 5.9 and $10.2 \%$. Haemoglobin, glucose, serum protein, iron and cholesterol were assayed by means of commercial kits (Lachema, Brno, Czech Republic). The feed analyses were done by standard AOAC (1980) procedures. The effects of virginiamycin and bST were evaluated by analysis of variance (SAS, 1982).

\section{RESULTS AND DISCUSSION}

The average daily weight gain of the calves was $0.52,0.57,0.55$ and $0.60 \mathrm{~kg}$, in the control, virginiamycin (V), bST and bST + $\checkmark$ groups, respectively (table I). The difference between the control and bST $+\mathrm{V}$ treatment was statistically significant $(P<0.05)$; the effects of the other treatments was not statistically significant. The intake of nutrients per $\mathrm{kg}$ of gain was nonsignificantly lower in the treated groups than in the control group. Neither haemoglobin, nor serum glucose, protein or cholesterol were significantly affected in the treated groups (data not shown). Serum iron levels, however, were increased in the bST $+V$ group at 10 weeks of age $(P<0.05)$. In the control and $V$ groups, the plasma concentrations of bST were low and varied, on average, between 3.0 and 13.9 ng. $\mathrm{ml}^{-1}$ (table II). In the bST and bST + V groups the plasma bST concentrations were elevated six- to ten-fold (30.1-89.3 ng.ml-1) throughout the 7 day injection interval. Compared to the control and $V$ groups, the differences were significant $(P<0.05)$ between 3 and $72 \mathrm{~h}$ postinjection for the bST group - and throughout the 7 day injection interval for the bST $+V$ group.

The data indicated that both growth promotors tested appeared to improve the performance of the female calves. The effects of virginiamycin and bST were additive: virginiamycin increased weight gain by $9.6 \%$, bST treatment by $5.8 \%$ and their combination by $15.4 \%$. The dose of $100 \mathrm{mg}$ of the recombinant bST in a sustained release vehicle per calf once a week was sufficient to obtain stable plasma bST concentrations up to ten-fold higher than those in untreated 
Table I. Performance and feed intake in control and treated female calves.

\begin{tabular}{lclll}
\hline & Control & $V^{\prime}$ & $b S T^{2}$ & $b S T+V$ \\
\hline Initial weight $(\mathrm{kg})$ & $51.6(3.9)$ & $52.6(3.2)$ & $50.6(3.1)$ & $49.2(2.4)$ \\
Final weight $(\mathrm{kg})$ & $88.0(2.6)$ & $92.4(3.4)$ & $89.2(2.1)$ & $91.4(2.4)$ \\
Daily gain (kg) & $0.52(0.05)$ & $0.57(0.04)$ & $0.55(0.04)$ & $0.60(0.04)^{\star}$ \\
& & & & \\
Total feed intake per animal & & & & \\
Skimmed milk (kg DM) & $14.0(0.1)$ & $14.0(0.1)$ & $14.0(0.1)$ & $13.8(0.1)$ \\
Starter (kg) & $60.7(0.7)$ & $61.6(0.7)$ & $58.8(1.7)$ & $61.3(1.2)$ \\
Meadow hay (kg) & $29.4(0.6)$ & $29.3(0.7)$ & $28.4(1.1)$ & $28.8(1.5)$ \\
Maize silage (kg) & $15.4(0.6)$ & $16.7(0.5)^{\star}$ & $14.9(0.6)$ & $16.1(0.5)$ \\
& & & & \\
Intake of nutrients per kg of gain & & & & \\
Dry matter (kg) & $2.64(0.34)$ & $2.58(0.25)$ & $2.36(0.30)$ & $2.34(0.29)$ \\
Digestible protein (kg) & $0.30(0.04)$ & $0.30(0.02)$ & $0.27(0.04)$ & $0.27(0.04)$ \\
Net energy (MJ) & $16.5(2.0)$ & $16.1(2.4)$ & $14.8(2.2)$ & $14.8(1.8)$ \\
& & & & \\
\hline
\end{tabular}

1 Virginiamycin ( $80 \mathrm{mg}$ per calf daily); ${ }^{2}$ bovine somatotropin (100 mg weekly); ${ }^{*}$ significantly different from control at $P<0.05$. Five calves per group. Standard deviations are given in parentheses.

Table II. Concentration of bovine somatotropin (bST) in plasma in control and treated female calves before and after the last bST application.

\begin{tabular}{|c|c|c|c|c|c|c|c|}
\hline \multirow{3}{*}{$\begin{array}{l}\text { Treatment } \\
\text { group }\end{array}$} & \multicolumn{7}{|c|}{ bST concentration (ng. $\mathrm{mr}^{-1}$ ) } \\
\hline & \multirow{2}{*}{$\begin{array}{c}\text { Before } \\
\text { injection }\end{array}$} & \multicolumn{6}{|c|}{ After injection (h) } \\
\hline & & 3 & 24 & 48 & 72 & 96 & 144 \\
\hline Control & $\begin{array}{l}10.7^{\mathrm{a}} \\
(3.3)\end{array}$ & $\begin{array}{l}8.5^{a} \\
(1.6)\end{array}$ & $\begin{array}{l}13.9^{a} \\
(8.6)\end{array}$ & $\begin{array}{l}8.0^{\mathrm{a}} \\
(3.6)\end{array}$ & $\begin{array}{l}6.6^{\mathrm{a}} \\
(3.0)\end{array}$ & $\begin{array}{l}9.2^{\mathrm{a}} \\
(3.4)\end{array}$ & $\begin{array}{l}7.1^{\mathrm{a}} \\
(3.7)\end{array}$ \\
\hline$V^{1}$ & $\begin{array}{l}5.6^{\mathrm{a}} \\
(2.1)\end{array}$ & $\begin{array}{l}7.9^{\mathrm{a}} \\
(3.6)\end{array}$ & $\begin{array}{l}10.3^{a} \\
(3.1)\end{array}$ & $\begin{array}{l}8.4^{\mathrm{a}} \\
(3.0)\end{array}$ & $\begin{array}{l}4.3^{a} \\
(2.7)\end{array}$ & $\begin{array}{l}3.0^{\mathrm{a}} \\
(2.0)\end{array}$ & $\begin{array}{l}4.8^{\mathrm{a}} \\
(2.8)\end{array}$ \\
\hline $\mathrm{bST} \mathrm{T}^{2}$ & $\begin{array}{l}37.8^{\mathrm{ac}} \\
(14.1)\end{array}$ & $\begin{array}{l}54.7 \mathrm{~b} \\
(15.1)\end{array}$ & $\begin{array}{l}72.7^{\mathrm{b}} \\
(26.8)\end{array}$ & $\begin{array}{l}36.0^{\mathrm{b}} \\
(13.9)\end{array}$ & $\begin{array}{l}31.8^{\mathrm{b}} \\
(12.8)\end{array}$ & $\begin{array}{l}30.1^{\mathrm{ac}} \\
(10.5)\end{array}$ & $\begin{array}{l}31.0^{\mathrm{ac}} \\
(7.5)\end{array}$ \\
\hline $\mathrm{bST}+\mathrm{V}$ & $\begin{array}{l}53.8^{b} \\
(31.1)\end{array}$ & $\begin{array}{l}85.4^{b} \\
(39.6)\end{array}$ & $\begin{array}{l}89.3^{b} \\
(22.0)\end{array}$ & $\begin{array}{l}47.2^{b} \\
(16.2)\end{array}$ & $\begin{array}{l}43.1^{b} \\
(18.1)\end{array}$ & $\begin{array}{l}40.3^{b c} \\
(21.7)\end{array}$ & $\begin{array}{l}38.0^{b} \\
(16.4)\end{array}$ \\
\hline
\end{tabular}

\footnotetext{
1 Virginiamycin ( $80 \mathrm{mg}$ per calf daily); ${ }^{2}$ bovine somatotropin (100 $\mathrm{mg}$ weekly). Values are means \pm SD (in parentheses) of five observations (five calves); $a, b, c$ values in the same column with unlike superscript letters differ significantly $(P<0.05)$.
} 
animals. The effects of virginiamycin on the performance and feed conversion reported in this study were similar to those reported previously (Daenicke, 1988; Marounek et al, 1992). In addition, the effects of bST on calf performance were consistent with older reports. The combination of a feed antibiotic and bST has not been tested in calves to our knowledge. In dairy cows, Murphy et al (1994) studied the effects of avoparcin, bST and the effects of both avoparcin and bST on measures of production. Treatment with bST significantly increased milk yield by $3.8 \mathrm{~kg} /$ day and treatment with bST + avoparcin by $5.1 \mathrm{~kg} /$ day. The difference in milk yield between both treated groups was, however, not significant.

Reports on the effects of commercial growth-promoting agents on endocrine factors in ruminants are scarce. Monensin increased serum growth hormone and glucagon levels in the plasma of lactating goats (Brown and Hogue, 1987). Intravenously administered monensin initially decreased and subsequently increased serum insulin levels in heifers (Armstrong and Spears, 1988). Lasalocid and cationomycin fed to sheep, however, did not affect their plasma insulin levels (Gomez and Jouany, 1994). In bulls, salinomycin and avoparcin significantly increased the plasma concentration of IGF-I, consequently improving the nutrient supply for the animals (Jahreis et al, 1993). In the present study, virginiamycin tended to increase the growth rate, but failed to increase the plasma concentrations of bST. The highest bST concentrations were found in the bST $+V$ group, ie, in animals with the highest growth rate. Differences between bST- and $\mathrm{bST}+\mathrm{V}$ calves were, however, not significant. It should be mentioned in this respect, that the endogenous bST secretion is pulsatile, which makes an accurate quantification of bST production difficult (Davies et al, 1977).

\section{ACKNOWLEDGMENT}

This study was supported by grant nos $505 / 93 / 1251$ and 505/93/1283 of the Grant Agency of the Czech Republic.

\section{REFERENCES}

Anderson KL, Nagaraja TG, Morrill JL, Reddy PG, Avery TB, Anderson NV (1988) Performance and ruminal changes of early-weaned calves fed lasalocid. $J$ Anim Sci 66, 806-813

Armstrong JD, Spears JW (1988) Intravenous administration of ionophores in ruminants: effects on metabolism independent of the rumen. J Anim Sci 66, 1807-1817

AOAC (1980) Association of Official Analytical Chemists. Official Methods of Analysis. Washington DC, USA

Brown DL, Hogue DE (1987) Effect of feeding monensin to lactating goats: acetyl coenzyme A carboxylase, hormone-sensitive lipase, plasma glucose, and circulating hormones. J Dairy Sci 70, 823-830

Brown LD, Jacobson DR, Everett JP, Seath DM, Rust JW (1960) Urea utilization by young dairy calves as affected by chlortetracycline supplementation. J Dairy Sci 43, 1313-1321

Brumby PJ (1959) The influence of growth hormone on growth in young cattle. $N Z J$ Agric Res 2, 683-689

Daenicke R (1988) Zum Wirksamkeit des Leistungsförderers Stafac Virginiamycin in der Kälberaufzucht. Rinderwelt 13, 99-101

Davis SL, OhIson DL, Klindt J, Anfinson MS (1977) Episodic growth hormone secretory patterns in sheep: relationship to gonadal steroid hormones. Am J Physiol 233, E 519-E 523

Gomez L, Jouany JP (1994) Effects of lasalocid and cationomycin on the evolution of certain parameters in the blood plasma of sheep. Arch Anim Nutr 46, 283-293

Groenewegen PP, McBride BW, Burton JH, Elsasser TH (1990) Effect of bovine somatotropin on the growth rate, hormone profiles and carcass composition of Holstein bull calves. Domest Anim Endocrinol 7, 43-54

Ilan D, Ben-Asher A, Holzer Z, Nitsan Z, Nir I, Levy D (1981) Effect of monensin supplementation on growth, feed digestibility and utilization in young calves. Anim Prod 32, 125-131

Jahreis G, Flachowsky G, Ochrimenko WI, Kauf E (1993) Einfluss von Salinomycin und Avoparcin auf die IGF -I-Konzentration im Plasma und das Wachstum von Mastbullen. Mh Vet Med 48, 203-209 
Kirchgessner M, Roth FX, Schams D, Karg H (1987) Influence of exogenous growth hormone $(\mathrm{GH})$ on performance and plasma GH concentrations of female veal calves. J Anim Physiol Anim Nutr 58, 50-59

Likhite V, Sehon A (1967) Protein conjugation. In: Methods in Immunology and Immunochemistry (CA Williams, MW Chase, eds), Academic Press, New York, USA, 1, 150-167

Marounek M, Skrivanová V, Macharová L (1989) Effect of monensin on digestibility of nutrients, ruminal volatile fatty acids and blood parameters in young calves. Landwitsch Forschung 42, 273-280

Marounek M, Podsedníček M, Petr O (1992) Effect of virginiamycin on performance and rumen parameters of young calves. Živoč Vyroba $37,721-726$

Moughan PJ, Stevens EVJ, Reisima ID, Rendel J (1989) The effect of avoparcin on the ileal and feacal digestibility of nitrogen and amino acids in the milkfed calf. Anim Prod 49, 63-71

Murphy MG, O'Callaghan D, Rath M, Austin FM, Rocke JF (1994) Effect of avoparcin and bovine somatotropin on measures of production and reproduction in dairy cows. Anim Prod 59, 321-326

NRC (1978) National Research Council. Nutrient Requirements of Dairy Cattle, 5th edn, no 3, National Academy of Sciences, Washington, DC, USA
Sandles LD, Peel CJ (1987) Growth and carcass composition of pre-pubertal dairy heifers treated with bovine growth hormone. Anim Prod 44, 21-27

SAS (1982) Users' Guide: Statistics. SAS Institute, Inc, Cary, NC, USA

Sk'ivanová V, Marounek M (1993) Effect of virginiamycin on feed intake, daily gains, ruminal volatile fatty acids and blood parameters in veal calves. Arch Anim Nutr 44, 41-46

Skł̌ivanová V, Marounek M, Šimünek J, Benda V (1994) Effect of virginiamycin on digestibility of nutrients, blood and immunologic parameters, and quality of meat in veal calves. J Agric Sci 123, 275-278

Slaba J, Krejči P, Škarda J, Huybrechts LM, Decuypere E, Herrmann H (1994) Plasma profiles of somatotropin and IGF-I in dairy cows following application of two preparations of recombinant bovine somatotropin in a sustained release vehicle. Physiol Res $43,37-43$

Thorell JL, Johansson BG (1971) Enzymatic iodination of polypeptides with ${ }^{125}$, to high activity. Biochim Biophys Acta 251, 363-369

Williams PEV, Innes GM, Odgen K, James S (1987) The effects of a combination of the $\beta$-agonist clenbuterol and bovine pifuitary growth hormone on growth of milk-fed calves. Anim Prod 45, 475 (abstr) 